\title{
Exploring network literacy among students of St. Joseph's Theological Institute in South Africa
}

\author{
Patrick Ngulube \\ University of South Africa, Department of Information Science, South Africa \\ ngulup@unisa.ac.za
}

Mhlukanisi Shezi ${ }^{2}$ and Athol Leach ${ }^{3}$

University of KwaZulu-Natal, School of Sociology and Social Studies, Information Studies Programme Shezim@ukzn.ac.za and Leach@ukzn.ac.za

Received: 10 November 2008

Accepted: 14 May 2009

\begin{abstract}
The main purpose of this study was to explore the level of network literacy among theological students at St. Joseph's Theological Institute. The survey research method was used and the data collected through a self-administered questionnaire and an in-depth interview with the Librarian. The entire population of 188 students was surveyed; only 65 students responded. Findings revealed that the major problems facing Internet users at St. Joseph's were the shortage of computers and lack of training in the use of Internet facilities. Further, students did not use a wide variety of Internet resources, had limited skills and knowledge to access networked information resources and made limited use of computermediated communication tools. Recommendations concerning network literacy at the Institute were made and suggestions for further research are put forward.
\end{abstract}

Keywords: Information Retrieval, Internet, Internet use, information seeking, network literacy, user studies

\section{Setting the scene}

This article describes a study which was carried out at St. Joseph's Theological Institute in South Africa in 2007. The purpose of the study was to explore the level of network literacy among theological students in order to form a better understanding of their level of network literacy and use of the Internet. Although a review of the literature shows that there are numerous studies on the use of the Internet, the concept of network literacy has not been widely researched (Savolainen, 2002; Shezi, 2006; Ngulube and Thompson, 2008). The results of this study have implications for both the use of the Internet and network literacy among the students at St. Joseph's Theological Institute.

Since the Internet is an important learning tool at the tertiary education level, it is argued that investigating the use of the Internet and network literacy at St. Joseph's will help to identify problems which are experienced by students in information seeking and provide strategies to resolve them. That may facilitate more effective use of the Internet by students at the Institute. Without the information that such a study might yield, it may be quite difficult for the Librarian and stakeholders at the St Joseph's Library to determine whether an expensive ICT tool like the Internet, (i.e. in the developing world context), is being used effectively or not. Moreover, network literacy is important in that it may assist the theological students at St Joseph's to participate in the information economy more effectively than before. That also has a possibility of bridging the digital divide which is prevalent in Africa.

The Internet and the World Wide Web (WWW) have played a significant role in revolutionising access to, location and use of information. The Internet, a network of networks, provides access to remote computers, electronic mail, file transfer, global bulletin boards, discussion lists, web blogs, wikis and a variety of tools to share and disseminate information. Advantages associated with the use of the Internet, which may also apply to students at St. Joseph's Theological Institute are as follows (Adogbeji and Akporhonor, 2005; Anderson, 200I; Ani, Uchendu and Atseye, 2007; Chifwepa, 2003; Davis, 2002; Ellsworth, 1994; Healey, 2004; Hong, Ridzuan and Kuek, 2003; Jagboro, 2003; Jones, 2002; Kaur and Manhas, 2008; Ke, 2002; Lindsay and Mclaren, 2000; Luambano and Nawe, 2004; Lubans, 1999; Madhusudhan, 2007; Nachmias and Segev, 2003; Ngai et al., 2008; Ngulube and Thompson, 2008; Norwegian Historian visits UniZulu, 2000; Ojedokun, 200 I; Olalude, 2007; Olatokun, 2008; Omotayo, 2006; Perry, 1998; Scherer, 1997; Spennemann, 2007; Urrehman, 2000):

- accessing information which is important to their studies and research;

- applying global knowledge;

I. . Patrick Ngulube (PhD), is a Professor of Information Science, University of South Africa, Pretoria and Editor-in-Chief of the ESARBICA Journal: Journal of the Eastern and Southern Africa Regional Branch of the International Council on Archives.

2. . Mhlukanisi Shezi, Librarian, University of KwaZulu-Natal.

3. . Athol Leach, is a Lecturer Information Studies Programme, School of Sociology and Social Studies, University of KwaZulu-Natal. 
- accessing non-traditional sources of information worldwide;

- keeping in touch with friends, relatives, fellow students and lecturers;

- transferring information from the teacher/lecturer to the student;

- providing access to the WWW as well as e-mail and related Internet activities;

- providing student support and supplementing classroom instruction;

- it is an accommodating and less threatening medium than face-to-face communication;

- facilitating instant messaging and online chat;

- making exploration of information easier than in print - based resources;

- promoting academic excellence;

- increasing creativity;

- serving as an essential tool for information processing and delivery;

- quickening transmission of information;

- broadening users' horizons beyond the local boundaries;

- providing an environment where impact may be immeasurable;

- easing communication;

- producing material on-line for others;

- acquiring technical training on-line;

- modernising tools of learning, teaching and research;

- providing much of the information available free of charge;

- providing access to information 24/7;

- enhancing the quality of reference services;

- sharing resources; and

- offering the opportunity for access to up-to-date research reports and knowledge globally.

In spite of the advantages enumerated above, there is limited use of the Internet on the part of some users due to their poor level of network literacy which was described by Barry (1997) and Savolainen (2002) as:

- knowledge of information resources available on the Internet;

- skilful use of ICT tools to access networked sources;

- judgement of the relevance of information; and

- use of computer-mediated communication tools.

Barry (1997) and Savolainen (2002) based their opinions on McClure (1994), the pioneer in the field, to define network literacy as the quality or state of being able to identify, access and use electronic information from the information network. The network competence model of Savolainen (2002: 223-4) offers a useful starting point in understanding information seeking in a networked environment. The four major areas of network literacy enumerated above formed the basis of the research questions that guided the research. The research questions were formulated as follows:

- Do theological students have knowledge of information resources available on the Internet?

- How do theological students use available information and communication technologies (ICTs) tools to access networked sources?

- How do theological students judge the relevance of information they retrieve from the Internet?

- To what extent do theological students use computer-mediated communication tools?

\section{Scope and limitation of the study}

Effective participation in the information society needs one to be information literate. The four dimensions of information literacy that assist people to acquire, process, understand and utilise information to solve problems, make decisions and become effective lifelong learners are traditional literacy, computer literacy, media literacy and network literacy (Hu, 1996; Martin, 2006; McClure, 1994; Wen and Shih, 2006). Although the four concepts are related, they differ in information content and the level of utilisation of information technology tools in each category (Bruce, 1997; Savolainen, 2002). This study is limited to the last aspect of information literacy listed above, because the area has not been adequately researched as stated in the previous section.

The study is set at St. Joseph's Theological Institute, which is situated near Pietermaritzburg in the Hilton District of KwaZulu-Natal in South Africa. It is predominantly populated by black students from former disadvantaged communities. St. Joseph's is a Catholic theological institution. There were three academic departments at the Institution at the time of the study, namely Philosophy, Theology and Religious Studies. The three academic departments at the institution offered a two-year diploma and a three-year Bachelor's degree in each discipline.

Access to the Internet was introduced in 2003 via 70 computers, which were housed in the Denis Hurley Memorial Library. This acquisition stirred the Library into the information technology age. This study was done in 2007 , three years 
after the introduction of the Internet at St Joseph's. The choice was influenced by the fact that past research has shown that students' search information skills using the Internet are initially inadequate (Barry, 1997; Hildreth, 1997; Scott and O'Sullivan, 2005; Tsai and Tsai, 2003).

\section{A brief research story}

The researchers considered the survey approach as the most appropriate method in terms of ascertaining an overall picture of the use of the Internet at St. Joseph's and the network literacy of the students. According to the literature, survey research is capable of collecting background information and hard-to-find data, and the researcher usually does not have the opportunity to motivate or influence the respondents' responses (Babbie and Mouton, 200I; Busha and Harter, 1980; Payne and Payne, 2004).

The survey research method was also used in the study of Internet use among students in Botswana (Ojedokun, 200I), Nigeria (Adogbeji and Akporhonor, 2005; Jagboro, 2003; Oghenevwogaga and Oghenevwogaga, 2006; Omotayo, 2006), South Africa (Shezi, 2006) and Tanzania (Chachage, 200I; Luambano and Nawe, 2004). A pre-tested selfadministered questionnaire was distributed to all 188 students registered at St. Joseph's Institute. Data from the questionnaire was supplemented by an in-depth semi-structured interview with the Librarian. The questionnaire was based on a review of those included in related studies (Chu and Law, 2007; Compton, 1989; Ojedokun, 2001).

Students were asked to deposit the completed questionnaires in a box marked 'Internet use survey' at the entrance of the library. The questionnaire was distributed in the classroom during lessons in order to make contact with the respondents and to encourage the return of the questionnaire. Follow-up visits to the classrooms were made after two weeks of the initial distribution of the questionnaires. In certain instances, copies of the questionnaires were given to some students who claimed to have misplaced their original questionnaires. Out of the I88 questionnaires handed out only 65 (34.6\%) were returned.

Despite several reminders and follow-ups, the response rate remained very low. It was towards the end of the school term and some of the students were focusing on going home. According to Babbie and Mouton $(2001: 261)$ the consensus in survey research was that a response rate of $50 \%$ was considered adequate for analysis, while $60 \%$ was good and $70 \%$ was considered to be very good. Nonetheless, the researchers in the current study were given the confidence to analyse the results and present their findings despite a low response. Payne and Payne (2004:222) pointed out that the typical response rate for self-completion surveys was $33 \%$. The survey data was also supplemented by the interview with the $\mathrm{Li}-$ brarian. Furthermore, the responses that we received resembled the original sample.

\section{Major research findings and discussion}

The general Internet use patterns of the students are presented first, followed by an examination of the four research questions that guided the study. Of the 65 students who completed the questionnaires, 34 (52.3\%) had used the Internet and 31 ( $47.7 \%)$ had not. Of 24 respondents who gave reasons for not having used the Internet, $17(70.8 \%)$ respondents said that they had not received formal training and did not know how to use the Internet. The in-depth interview with the Librarian confirmed that there was no formal training provided to the students when the Internet was introduced at the institution in 2003. Lack of knowledge and skills to use the Internet has been highlighted in the literature as the main reason for non-use of the facility (Adogbeji and Akporhonor, 2005; Chachage, 200I; Leelavathi and Doraswamy, 2007; Luambano and Nawe, 2004; Ojedokun, 200I; Omotayo, 2006; Shezi, 2006).

The shortage of computers and slow computer speeds were mentioned by $13(54.2 \%)$ respondents. Ten (4I.7\%) pointed to the unavailability of computers with Internet facilities. Inadequate provision of computers with Internet facilities and the slow speed of computers were identified by past research as the reasons why students in an African academic environment were not using the Internet effectively (Ehikhamenor, 2003; Luambano and Nawe, 2004; Mgobozi and Ocholla, 2002; Mishra, Yadav and Kamini, 2005; Odero-Musakali and Mutula, 2007; Ojedokun, 200I).

The majority of respondents 18 (52.9\%) who were using the Internet said that they were self-taught. In his study of the use of the Internet by Tanzanian students, Chachage (200I: 231 ) found that $56 \%$ of participants had never had any training on the use of the Internet at all. Furthermore, some $26 \%$ had trained themselves through Internet tutorials and by the use of the trial and error method. Similarly, Renwick (2005) and Salmon (2002) revealed that the majority of users of the Internet at the University of the West Indies were self-taught. Further, Gietzelt (200I: 142) found that one third of the students that were investigated had learned to use a computer through informal mechanisms. The same scenario obtained at an Indian university among faculty members (Leelavathi and Doraswamy, 2007).

The largest number $16(47.1 \%)$ of respondents were using the Internet for accessing academic related materials. This was followed by those using the Internet to obtain news from around the world, mentioned by eight $(23.5 \%)$ of the respondents. Similarly, Ojedokun (200I: 103) in his study found that $290(19.6 \%)$ respondents rated access to news 
items as the second major use of the WWW. Gietzelt (200I: 145) also revealed that 21 (64\%) respondents who accessed the WWW frequently visited news sites. Research, however, confirms that the majority of the students in academic environments use the Internet for educational purposes (Kaur and Manhas, 2008).

The respondents were asked to make some comments and suggestions about the use of the Internet. Eight of the respondents did so. Comments and suggestion given by the eight respondents varied and each comment and suggestion is listed in Table I. The comments in Table I are in resonance with those commonly found in the literature (Ehikhamenor, 2003; Luambano and Nawe, 2004; Mishra, Yadav and Kamini, 2005; Odero-Musakali and Mutula, 2007; Ojedokun, 200I).

Table I Comments and suggestions on the use of the Internet

\begin{tabular}{|c|c|}
\hline Comments and suggestions & Frequency \\
\hline "I wish I had better knowledge about the use of the Internet" & 1 \\
\hline "I think that net is a wonderful way of knowing, exchanging and meeting people" & 1 \\
\hline "Time allocation for net use is limited" & 1 \\
\hline "I wish everyone can have access to the net since it is very good" & 1 \\
\hline $\begin{array}{l}\text { "Internet is a good tool that students should be used to, and encouraged to use. Proper Internet services } \\
\text { should be provided at St. Joseph's Institute" }\end{array}$ & 1 \\
\hline "More computers or a computer room or library would also help the access at the net" & 1 \\
\hline "The Institute should improve the quality of computers and training for the use of net" & 1 \\
\hline "Such technology is needed and necessary in every Institute of learning" & 1 \\
\hline Total & 8 \\
\hline
\end{tabular}

4.1 Knowledge of information resources available on the Internet

Following Savolainen (2002), knowledge of information resources in this article refers to familiarity with a range, the organisation, use and role of networked resources. The range of information resources on the Internet includes directories, subject guides, subject gateways, portals, home pages, web blogs, wikis, e-mail, listservs and search engines. Students in an academic environment are likely to use some of these sources for research and other purposes if they have knowledge of their existence.

Knowledge of information available on the Internet may be established by exploring the kinds of sources the students use and the extent to which they use these various source types (Chang and Perng, 200I; Compton, 1989). Students were given a list of categories from which to choose the information resources they used. The "other" category in all the questionnaire items in this section was not responded to. The categories of source types used in Table 2 were adapted from Chu and Law (2007: 31).

Table 2 Rate of use of web-based information resource $\mathrm{N}=34$

\begin{tabular}{|c|c|c|c|c|c|c|}
\hline \multirow[t]{7}{*}{ Categories of source types } & Information resource & Use always & Use some times & No opinion & Rarely use & Never use \\
\hline & E - Journals & $5(14.7 \%)$ & $16(47.1 \%)$ & - & $\mathrm{II}(32.4 \%)$ & $2(5.9 \%)$ \\
\hline & Free web resources & $18(52.9 \%)$ & $7(20.6 \%)$ & $\mathrm{I}(2.9 \%)$ & $7(20.6 \%)$ & $\mathrm{I}(2.9 \%)$ \\
\hline & Portals & $3(8.8 \%)$ & $3(8.8 \%)$ & $17(50 \%)$ & $2(5.9 \%)$ & $9(26.5 \%)$ \\
\hline & E - databases & $21(61.8 \%)$ & $8(23.5 \%)$ & - & $5(14.7 \%)$ & - \\
\hline & $\mathrm{E}$ - theses & $\mathrm{I}(2.9 \%)$ & - & - & $\mathrm{I}(2.9 \%)$ & $32(94.1 \%)$ \\
\hline & E - prints & $2(5.9 \%)$ & $\mathrm{I}(2.9 \%)$ & - & $2(5.9 \%)$ & $29(85.3 \%)$ \\
\hline \multirow[t]{2}{*}{ Research - oriented sources } & E - books & $3(8.8 \%)$ & - & - & $7(20.6 \%)$ & $24(70.6 \%)$ \\
\hline & $\begin{array}{l}\text { Online discussion groups } \\
\text { (mailing lists \& news groups) }\end{array}$ & $\mathrm{I}(2.9 \%)$ & - & $2(5.9 \%)$ & $6(17.6 \%)$ & $25(73.5 \%)$ \\
\hline Contact with research community & Technical reports & $3(8.8 \%)$ & - & - & - & $31(91.2 \%)$ \\
\hline \multirow[t]{3}{*}{ Professional sources } & Trade journals & $7(20.6 \%)$ & $8(23.5 \%)$ & - & - & $19(55.9 \%)$ \\
\hline & Encyciopedia & $9(26.5 \%)$ & $16(47.1 \%)$ & - & $9(26.5 \%)$ & - \\
\hline & Bibliographies & $7(20.6 \%)$ & $16(47.1 \%)$ & - & $\mathrm{II}(32.4 \%)$ & - \\
\hline \multirow[t]{3}{*}{ Academic reference tools } & Dictionaries & $10(29.4 \%)$ & - & - & $12(35.3 \%)$ & $12(35.3 \%)$ \\
\hline & Newspapers & $17(50 \%)$ & - & - & $8(23.5 \%)$ & $9(26.5 \%)$ \\
\hline & Magazines & $7(20.6 \%)$ & $12(35.3 \%)$ & $\mathrm{I}(2.9 \%)$ & $12(35.3 \%)$ & $2(5.9 \%)$ \\
\hline Media & Government Publications & $4(11.8 \%)$ & - & - & $3(8.8 \%)$ & $27(79.4 \%)$ \\
\hline
\end{tabular}


It is evident from Table 2 that the students were not frequently using most web-based information resources. Edatabases and free web resources were the most frequently used. That means they had limited access to the information required for problem-solving and academic endeavours that are widely available on the Internet. It is notable that ejournals, encyclopaedias and dictionaries were not always utilised by the majority of the respondents. Yet these sources can serve as a useful point of reference when one is embarking on a search for information on a subject that one might be unfamiliar with.

Adams and Bonk (1995) and Luambano and Nawe (2004) identified the problem of insufficient awareness of the information resources as the main barrier to the use of these Internet assets. However, the interview with the Librarian at St Joseph's Theological Institution also revealed that the low usage of Internet resources was partly due to the fact that some lecturers put more emphasis on printed sources than Internet information when guiding students to relevant information resources.

4.2 Skilful use of available information and communication technologies (ICTs) tools to access networked sources Studies have revealed that some students do not use the Internet because of their limited skills and knowledge (Luambano and Nawe, 2004; Ojedokun, 2003). According to Spitzberg and Cupach (1984: I I8), "[s]kills involve the ability to pragmatically apply, consciously or even unconsciously, our knowledge in practical settings". In other words, it is the application of our knowledge of how to do things in order to achieve a certain goal. Skills are required to locate, select and use networked information for problem solving and lifelong learning (Hu, 1996; McClure, 1994; Savolainen, 2002). The major variables that were measured to answer the research question on skills to operate in a networked environment were the kind of search engines they used to search the Internet, skills in navigating the Internet and formulating search queries.

Yahoo was listed as the most favourite search engine, being mentioned by 14 (4I.2\%) of the respondents. Yahoo was closely followed by Google with $12(35.3 \%)$ respondents. A number of search engines were not selected from the list provided by the researchers. Figure I provides further details. Ojedokun (200I: 104) and Omotayo (2006:219) also found in their research that Yahoo was the search engine most favoured by the respondents, closely followed by Google as in the current study. Studies conducted elsewhere outside Africa show that Google was the most-used search engine (Asemi, 2005; Kaur and Manhas, 2008; Julien and Barker, 2009; Madhusudhan, 2007). Meta-search engines such as Dogpile, which have the capability of searching for information from more than one search engine or subject directory at a time was not selected from the given list by any of the respondents

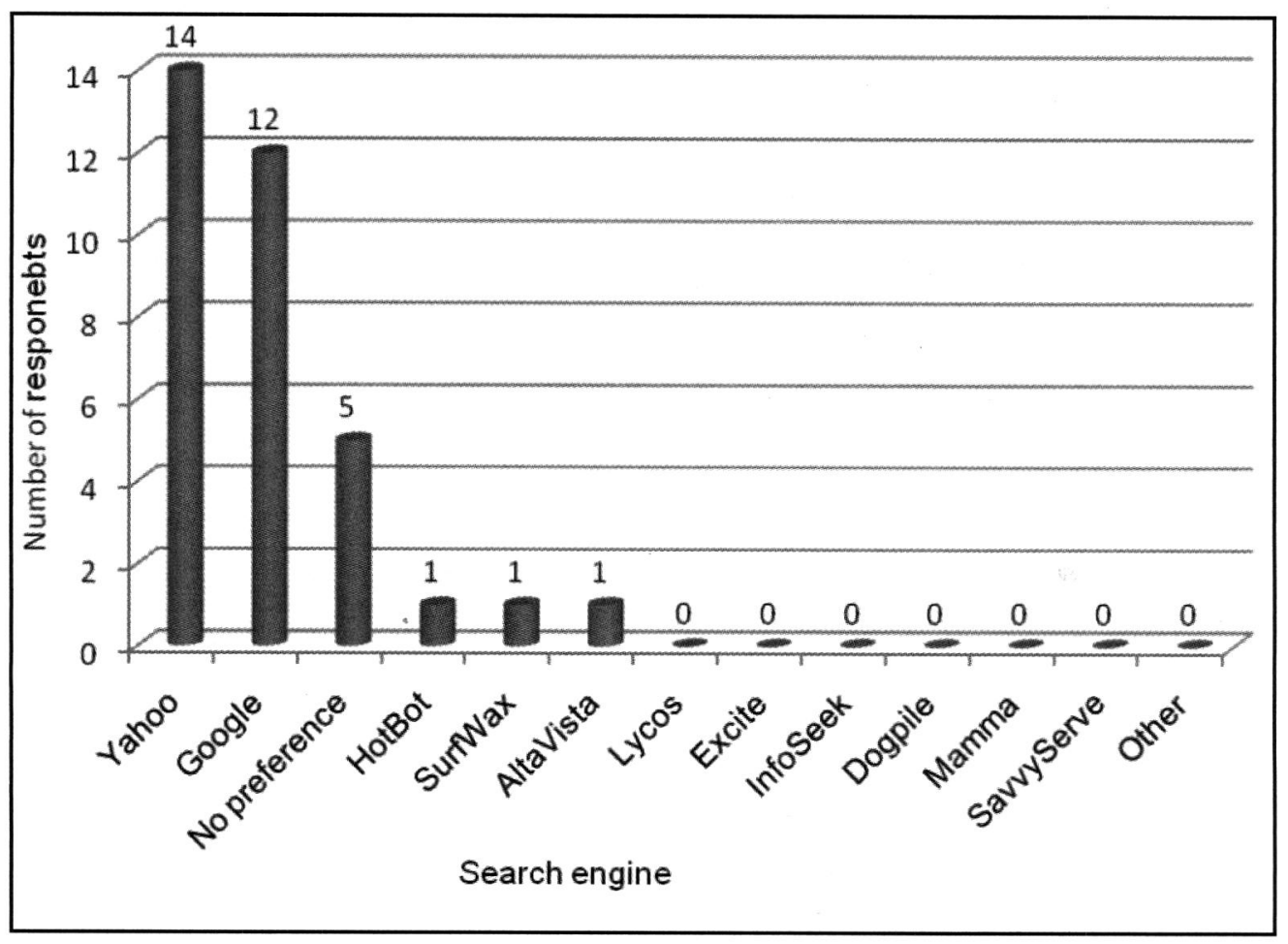

Figure 1 Favourite search engine preferred by the respondents $N=34$ 
Searching the Web demands time and effort and can lead to hours of unproductive browsing. Analytical searching, which according to Large, Tedd and Hartley (1999:143) is premised upon the user's identification of the correct search terms and relevant sources, is key to saving the searcher's time and yielding information that is closely related to the solution to the information problem. In that light, the study investigated the skills of the respondents in navigating the Internet and formulating search queries. Students were asked to rate their level of agreement using a five-point Likert scale with the statements that were provided in the questionnaire. The results are presented in Table 3.

Table 3 Skills in navigating the Internet and formulating search queries $N=34$

\begin{tabular}{|c|c|c|c|c|c|}
\hline Statement & Strongly agree & Agree & Neutral & Disagree & Strongly disagree \\
\hline Do not understand how a keyword search operates & $31(91.2 \%)$ & $2(5.89 \%)$ & - & $\mathrm{I}(2.9 \%)$ & - \\
\hline Do not understand how a subject search operates & $3 \mathrm{I}(9 \mathrm{I} .2 \%)$ & $2(5.89 \%)$ & - & $\mathrm{I}(2.9 \%)$ & - \\
\hline \multicolumn{6}{|l|}{ Familiar with a full range of operators, such as the } \\
\hline Boolean operators 'AND' and 'OR', and parenthesis ( ) & - & - & - & - & $34(100 \%)$ \\
\hline Use one type of database & $5(\mid 4.7 \%)$ & $7(20.6 \%)$ & - & $\mathrm{I}(2.9 \%)$ & $21(61.8 \%)$ \\
\hline $\begin{array}{l}\text { Understand that there are different databases available } \\
\text { for different purposes }\end{array}$ & $21(61.8 \%)$ & $\mathrm{I}(2.9 \%)$ & - & $7(20.6 \%)$ & $5(\mid 4.7 \%)$ \\
\hline Type the web address directly into the browser & $20(58.8 \%)$ & $13(38.2 \%)$ & - & $\mathrm{I}(2.9 \%)$ & - \\
\hline Familiar with the use of meta-search engines & - & - & - & $\mathrm{I}(2.9 \%)$ & $33(97.1 \%)$ \\
\hline \multicolumn{6}{|l|}{ Lack of knowledge of appropriate search engines to use } \\
\hline \multicolumn{6}{|l|}{ Largely depend on browsing to identify suitable } \\
\hline information from the Internet & $33(97.1 \%)$ & $\mathrm{I}(2.9 \%)$ & - & - & - \\
\hline
\end{tabular}

Table 3 reveals that the students had limited skills in navigating the Internet and formulating search queries. Following Large, Tedd and Hartley's (1999:181), characterisation of searching as either analytical or browsing, it is clear from Table 3 that their analytical search skills were not adequate. All the respondents strongly disagreed that they were familiar with Boolean operators, and $3 \mathrm{I}(9 \mathrm{I} .2 \%$ ) were unfamiliar with keyword search features. Browsing was the most attractive way of seeking information on the Internet to most respondents, as 33(97.1\%) strongly acknowledged their dependency on this informal way of seeking information. Browsing strategies are attractive to many users because it is "... interactive and opportunistic, depending upon the user recognising relevant information when it is encountered" and it "... highly depends on human perceptual abilities" (Large, Tedd and Hartley, 1999:181).

Navigating and browsing skills, formulating a search query (Barry, 1997: 225) are essentials skills in a networked environment. The challenges and frustrations associated with Web searching may be alleviated by having proper skills to navigate the Internet and providing an appropriate search query. That can also reduce the information overload and the noise associated with the Internet. The results do suggest that the respondents do not have all the necessary search skills. Low search abilities of end-users were also reported by Monopoli et al., (2002) among e-journal users at a university in Greece, and by Adogbeji and Akporhonor (2005) in the case of Internet users in Nigeria.

\subsection{Judging the relevance of information retrieved from the Internet}

Tools such as directories, subject guides, subject gateways, portals, home pages, web-blogs, wikis, search engines, e-mail and listservs facilitate the identification, location, selection, interpretation, synthesis and evaluation of network resources. It is evident that a lot of information is available to users of the Internet. Information on the Internet may come in the form of facts, opinions, stories, interpretations, statistics, scandals, rumours and gossip (Harris, 2007). Some of the information has not been evaluated by scholars as in the traditional publishing environment. Digital literacy as described by Gilster (19977) is essential when dealing with networked resources.

It is necessary to determine the quality and relevance of information found on the Internet because anyone can write a Web page and no one has to approve content before it is made public (Gilster, 19977; Harris, 2007; Kirk, 1996). It is also difficult to hold people accountable for their content when it comes to a self-publishing and an inclusive medium such as the Web. Further, some web pages may be edited at will because in most cases editing a web page is easy, free and unmonitored. For instance, some websites allow people to remove or add information at will without any gate-keeping using wiki software. This is generally true of the Wikipedia encyclopaedia, for example.

SA JnI Libs \& Info Sci 2009, 75(I) 
The famous Steiner cartoon published in the New Yorker of 5 July 1993 comes to mind if one thinks of the anonymity associated with many Internet sources. The cartoon depicts two dogs sitting before a terminal looking at a computer screen. One says to the other: "On the Internet, nobody knows you're a dog" (Regents of the University of California, 2008). Such sentiments underscore the need to evaluate Internet sources for their quality and relevance. It is incumbent upon the users to establish the validity, timeliness and integrity of what they retrieve from the Internet.

Studies have shown that students have problems when it comes to evaluating information retrieved from websites (Scoot and O'Sullivan, 2005). This is exacerbated by the fact that the criteria for judging relevance of an information resource differ from scholar to scholar (see Savolainen and Kari, 2006). However, the researchers in the current study were convinced that the criteria that they adapted might shed light on some aspects of the network literacy of the respondents, including their ability to judge information relevance. A rough indication of how the informants perceived the relevance of Internet resources may be obtained from the questions that were asked. While we emphasise that the criteria that were chosen may be used to judge the quality and relevance of information that the respondents retrieve, we do concede that personal knowledge of the informants also comes into play when making judgement about relevance, as pointed out by Savolainen and Kari (2006). Models found in the literature were partly used as benchmarks to gauge the students' ability to evaluate Internet resources (Barry and Schamber, 1998; Savolainen and Kari, 2006).

Table 4 Criteria used to rate relevance of Internet information resources $N=34$

\begin{tabular}{|c|c|c|c|c|c|}
\hline Statement & $\begin{array}{l}\text { Strongly } \\
\text { agree }\end{array}$ & Agree & Neutral & Disagree & $\begin{array}{l}\text { Strongly } \\
\text { disagree }\end{array}$ \\
\hline $\begin{array}{l}\text { I am able to judge the trustworthiness of an Internet } \\
\text { source }\end{array}$ & $5(14.7 \%)$ & $7(20.6 \%)$ & - & $\mathrm{I}(2.9 \%)$ & $21(61.8 \%)$ \\
\hline $\begin{array}{l}\text { Determining the currency of an Internet source is a } \\
\text { high priority to me }\end{array}$ & $23(67.6 \%)$ & $7(20.6 \%)$ & - & $3(8.8 \%$ & $\mathrm{I}(2.9 \%)$ \\
\hline $\begin{array}{l}\text { I can judge the accuracy of the information retrieved } \\
\text { from the Internet }\end{array}$ & $\mathrm{I}(2.9 \%)$ & $\mathrm{I}(2.9 \%)$ & - & $\mathrm{I}(2.9 \%)$ & $31(91.2 \%)$ \\
\hline $\begin{array}{l}\text { I can easily distinguish misinformation and } \\
\text { disinformation }\end{array}$ & $5(14.7 \%)$ & $21(61.8 \%)$ & - & $\mathrm{I}(2.9 \%)$ & $7(20.6 \%)$ \\
\hline I question the information that I retrieve & $21(61.8 \%)$ & $\mathrm{I}(2.9 \%)$ & - & $7(20.6 \%)$ & $5(14.7 \%)$ \\
\hline I always verify information from unfamiliar sources & $21(61.8 \%)$ & $\mathrm{I}(2.9 \%)$ & - & $7(20.6 \%)$ & $5(\mid 4.7 \%)$ \\
\hline $\begin{array}{l}\text { The pertinence of the information to my research } \\
\text { topic informs my choice of a retrieved source }\end{array}$ & $29(85.3 \%)$ & $5(14.7 \%)$ & - & - & - \\
\hline $\begin{array}{l}\text { I assess the quality of a source retrieved from the } \\
\text { Internet }\end{array}$ & $5(14.7 \%)$ & $21(61.8 \%)$ & - & $\mathrm{I}(2.9 \%)$ & $7(20.6 \%)$ \\
\hline $\begin{array}{l}\text { I can choose pages that are likely to be reliable and } \\
\text { authentic }\end{array}$ & $9(26.5 \%)$ & $17(50 \%)$ & $\mathrm{I}(2.9 \%)$ & $3(8.8 \%)$ & $4(11.8 \%)$ \\
\hline
\end{tabular}

A pattern on how the respondents judged the relevance of Internet resources does not clearly emerge from the data. However, the inference that the respondents were not quite knowledgeable about evaluating and judging the relevance of Internet resources is inescapable, particularly when considering responses to the first and third statements in Table 4. We concede that assessing relevance is not simple, and we agree with Ruthven, Baillie and Elsweiler (2007) when they write that: "... the same person may judge the same document relevant or non-relevant at different points in time, even within a single search session. Different searchers may also disagree on the relevance of a document to a search request." In that light, we failed to conclusively measure the network literacy skills associated with this competency. Another approach may yield better results which moves beyond self-reporting by respondents (see Conclusions and recommendations below).

\subsection{Use of computer-mediated communication tools}

Computer-mediated communication (CMC) comprises electronic-mediated communication systems that facilitate human communication across time and distance (Meskill and Anthony, 2008; Olaniran, 2006). There are a number of computer-mediated tools which are freely available on the Internet. Some of the technologies include asynchronous tools such as emails, mail-bases, shared network group folders, annotatable web-pages and databases, discussion boards (or fora/forums), frequently updated hyperlinked web-pages and web blogs, and synchronous ones such as computer conferencing, video-conferencing, instant messaging (text, voice) and chat (Olaniran, 2006; Stevens, 2004). Yahoo Messenger ${ }^{\circledR}$ is an example of an instant messenger (IM). It is possible to detect friends who are logged online when using this tool. Yahoo Messenger ${ }^{\circledR}$ is arguably a more robust webcast tool than other freely available instant messenger tools (Stevens 2004). For instance, it allows multiple participation both in webcam and voice mode. 
Many applications and techniques such as e-mail, webcams, instant messaging, blogging, gaming, and photo and videosharing may facilitate students' collaborative and communication activities. The respondents' ability to use some of the network tools to share information is outlined in Figure 2.

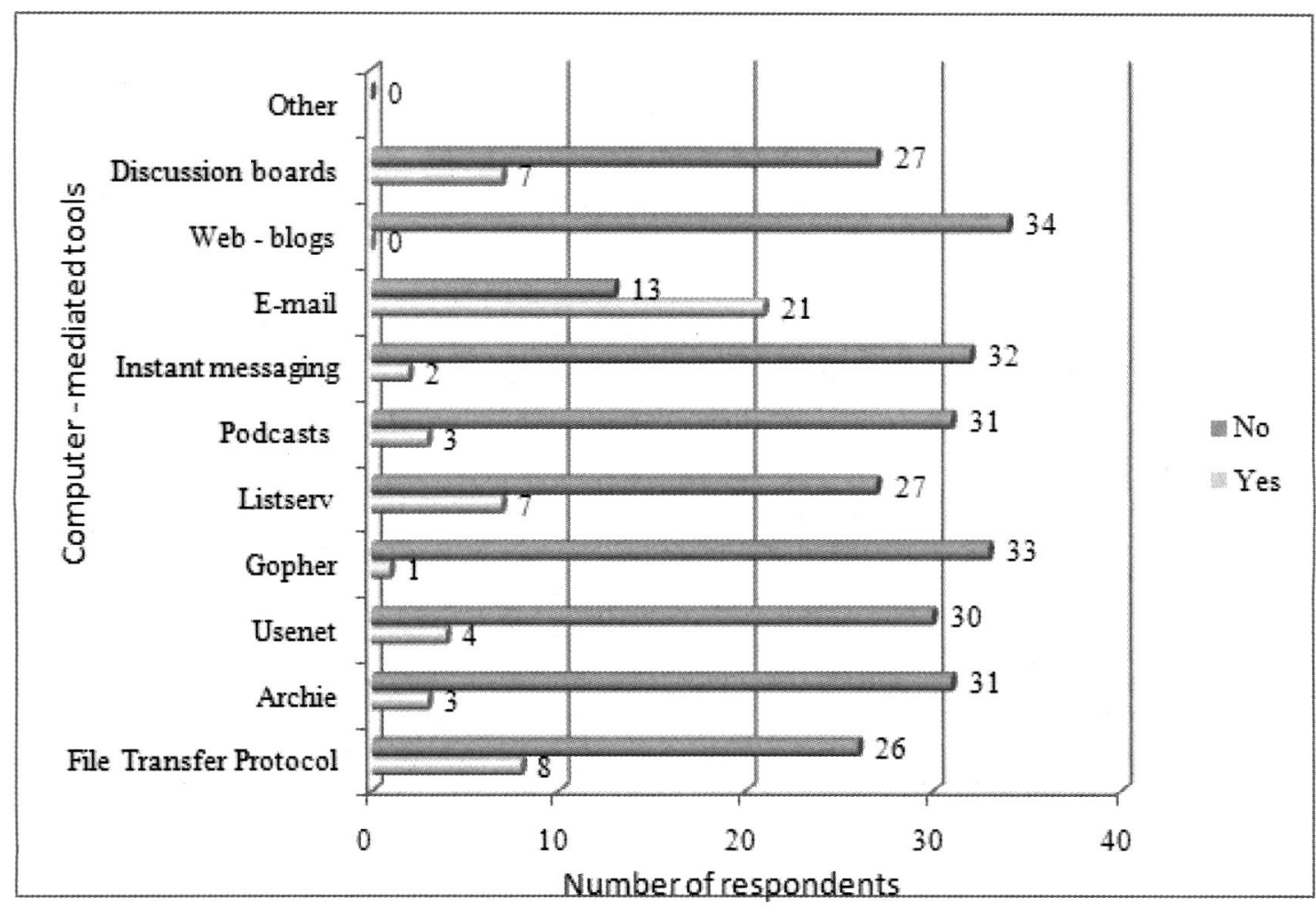

Figure 2 Using network tools to share information $\mathrm{N}=34$

The most frequently used facilities were e-mail 21 (61.8\%) followed by File Transfer Protocol (FTP) 8 (23.5\%). The literature revealed that in terms of usage, the major use of the Internet was e-mail (Chachage, 200I; Kaur and Manhas, 2008; Jagboro, 2003; Ojedokun, 200 I; Perry, 1998; Riahinia and Azimi, 2008; Urrehman, 2000). Contrary to the findings by Lancaster et al., (2007) instant messaging was not a popular communication technology in this particular college, as only two respondents reported the use of this Internet tool. Participation in discussion groups involved $7(20.6 \%)$ of the respondents.

Similarly, Jones (2002) found that Internet tools such as chat rooms, message boards and newsgroups were practically unused by the students who were surveyed. On the list, which was given to the respondents to choose from, there was also a choice of web blogs and podcasts, but it seems that no respondents had used these tools. The majority 26 (76.4\%) of respondents did not use FTP. The interview with the Librarian revealed a need for training in students' use of the Internet facilities. Ojedokun (2003: 49) in his study of Internet access and usage by students of the University of Botswana, reported the limited use of file transfer (via FTP) among students. Perhaps that suggested that the students were not skilled in the use of this facility. Thus, they were unable to share data sets, jointly write proposals and research papers, and engage scholars on a global basis in dialogue on research issues of interest to them.

According to the study by Hong, Ridzuan and Kuek (2003), students with better basic Internet skills were more positively predisposed toward using Internet tools for learning. Table 6 further explores the student's use of CMC for collaborative learning activities.

Table 5 Use of computer-mediated communication for collaborative activities $\mathrm{N}=34$

\begin{tabular}{|c|c|c|}
\hline Have used computer-mediated communication for any of the following? & Yes & No \\
\hline To support a videoconference & - & $34(100 \%)$ \\
\hline To provide further contact with a guest lecturer after their lecture & - & $34(100 \%)$ \\
\hline To provide additional opportunity for students to exchange ideas for subject areas that are more discursive & - & $34(100 \%)$ \\
\hline To enable students to meet when a face-to-face session is difficult to organise & $2(5.9 \%)$ & $32(94.1 \%)$ \\
\hline To exchange new ideas with other students & - & $34(100 \%)$ \\
\hline
\end{tabular}


The findings in Table 5 further confirm the low level of CMC by the respondents. The low level of use may be partly attributed to lack of awareness and training on these tools.

When further questioned concerning e-mail use, it was found that the vast majority 30 (88.2\%) of respondents had their own e-mail addresses. Just over half 16 (47.1\%) of respondents were using Yahoo mail as their e-mail account. This was followed by Hotmail, being used by $13(38.2 \%)$ of the respondents. The most common use of e-mail mentioned by $23(67.6 \%)$ respondents was to communicate with friends and relatives. Communicating with lecturers at St. Joseph's Theological Institute was indicated as the next main use of e-mail, mentioned by four (II.8\%) respondents. Jones' (2000) study of college students and Internet use also found that 19\% of students actually communicated more with their professors via e-mail than face-to-face. Jones (2000) made the observation that most students felt their relationships with their professors had been positively affected by e-mail and Internet communication in general.

\section{Conclusions and recommendations}

The present study investigated the use of the Internet by students at St. Joseph's Theological Institute in KwaZulu-Natal, South Africa. The study used a cross-sectional approach. A longitudinal approach may also be useful to gauge the students' information seeking habits over time. Longitudinal studies on end-user searching patterns are conspicuous by their absence in the literature (Chu and Law, 2008; Vàkkhari, Pennanen and Serola, 2003; Yuan, 1997).

The conclusions of the present study are guided by the research questions that the study sought to answer, and are outlined below. From the demographic details in the previous section, it is clear that 34 (52.3\%) students used the Internet and 31 (47.6\%) did not. The students who were using the Internet were the students who learned to use it through being self-taught, taught by friends and reading books. Moreover, the study revealed that when the Internet was introduced at the Institution, there was no formal training in Internet usage. Accessing academic related materials was the most common use of WWW. It was found that the Yahoo search engine was the favourite search engine. Finally, the major problems facing the Internet users at St. Joseph's were the shortage of computers and slow computers.

Respondents did not frequently use information resources available on the Internet. That might be indicative of the fact that they were unfamiliar with the resources. Their skills in the use of ICT tools to access information in a networked environment were limited. However, it not quite clear whether or not they can judge the relevance of information they retrieved from the Internet. Many applications and techniques such as webcams, instant messaging, blogging, and photo and video-sharing which may facilitate students' collaborative and communication activities were not widely utilised. In a nutshell, in most instances the respondents lacked expertise in network literacy. The results of this study seem to verify previous findings on the use of the Internet in an academic environment.

Based on the findings, we recommend that there should be more computers at St. Joseph's Theological Institute, since some of the respondents who did not use the Internet had said they had limited access to computers. Internet use is generally maximised by the availability of computers (Renwick, 2005). Training of the students to use the Internet is recommended, as some of the students who used (or did not use the Internet) did not have the necessary skills to do so. This may well encourage increased and more efficient use of the Internet, particularly in relation to finding academicrelated materials and engaging in collaborative activities. The Librarian should include network literacy issues in the information literacy instruction. This has the possibility of enabling students to compete in a world that is largely defined by the use of information technology. Skilful use of the Internet may enable students to effectively navigate the Internet, retrieve relevant information and exploit the advantages offered by computer mediated tools.

It is evident that use depends on the level of awareness of the Internet as a source of information, access to the Internet and skilful use of the Internet, and motivation to use it. As Nicholas (2000:10) wrote: "you can use what you know about and what you are experienced or trained in using". Then, training on and promotion of network resources should be one of the priorities of the Librarian. Raising their level of awareness of the existence of Internet resources will be equally important. Students should also be encouraged to use Google as it is touted as a search engine that can search the web better than others (Brin and Page, 1998; Regents of the University of California, 2008). Therefore, Yahoo should arguably only be used for a "second opinion" rather than as a search engine of choice.

Finally, the survey data should be treated with some caution. The sample that was studied was quite small as a result of a low response rate of $34.6 \%$. Since this study was exploratory, it is difficult to generalise the results. More representative conclusions could be drawn if further studies using a bigger sample size were conducted. Further studies may collect data through in-class library exercises which require the students to engage in activities to determine their network literacy instead of relying on self-reporting as was the case in the present study. The technology acceptance model (Weisband and Reinig, 1995), which seeks to explain the use, the intention to use and acceptance of new technology may be used in further studies to investigate the non-use of network technologies at the institution. Such a study would verify whether or not non-use of Internet tools may be mainly attributed to lack of expertise and training in network literacy, as was con- 
cluded by the current study. The question of judging the relevance of information retrieved from the Internet was not conclusively dealt with in this study. Further studies may use document selection models suggested in the literature (Savolainen and Kari, 2006; Wang and Soergel, 1998) to investigate the issue of judging the relevance of information that has been retrieved from the Internet.

\section{References}

Adams, J.A. \& Bonk, S.C. 1995. Electronic information technologies and resources: use by university faculty and faculty preferences for related library services. College and Research Libraries, 52(2): || $9-13 \mid$.

Adogbeji, O.B. \& Akporhonor, B.A. 2005. The impact of ICT (Internet) on research and studies. The experience of the Delta State University students in Abraka, Nigeria. Library Hi Tech News, 10:17-2I.

Anderson, K. 200I. Internet use among college students: and exploratory study. Journal of American College Health, 50(I): 6-2I.

Ani, O.E., Uchendu, C. \& Atseye, E. U. 2007. Bridging the digital divide in Nigeria: a study of internet use in Calabar Metropolis, Nigeria. Library Management, 28(6\&7):2007.

Asemi, A. 2005. Information seeking habits of Internet users: a case study on the Medical Sciences University of Isfahan (MUI), Iran. Webology, I(2). [Online]. http://www.webology.ir/2005/v2n I/a /0.html\#9. Accessed I0 March 2008.

Babbie, E. \& Mouton, J. 200I. The practice of social research. Cape Town: Oxford University Press.

Barry, C. A. 1997. Information skills for electronic world: training doctoral research students. Journal of Information Science, 23(3): 225-238.

Barry, C.L. \& Schamber, L. 1998. User's criteria for relevance evaluation: a cross-situational comparison. Information Processing and Management, 34(2-3): 219-36.

Brin, S. \& Page, L. 1998. The anatomy of a large-scale hypertextual Web search engine. Computer Networks and ISDN Systems, $30(1-7): 107-117$.

Bruce, C. 1997. The seven faces of information literacy. Adelaide: Auslib Press.

Busha, C. \& Harter, P. 1980. Research methods in librarianship: techniques and interpretation. New York: Academic Press.

Chachage, B.L. 200I. Internet café in Tanzania: a study of the knowledge and skills of end-users. Information Development, I7(4): 226-230.

Chang, N.C. \& Perng, J.H. 200I. Information search habits of graduate students of Tatung University. The International Information and Library Review, 33(4): 34I-346.

Chifwepa, V. 2003. The use of the intranet and internet by teaching staff of the University of Zambia. African Journal of Library, Archives and Information Science, 13(2): I19-132.

Chu, S.K.W. \& Law, N. 2007. Development of information search expertise: research student's knowledge of source types. Journal of Librarianship and Information Science, 39(I): 27-40.

Chu, S.K.W. \& Law, N. 2008. The development of information search expertise of research students. Journal of Librarianship and Information Science, 40(3): 165-177.

Compton, M.L. 1989. A study of the information resources and library services used by doctoral students in science education at the University of Georgia. Masters thesis, University of Georgia.

Davis, P.M. 2002. The effect of the web on undergraduate citation behaviour. College and Research Libraries, 63(I): 6-53.

Ehikhamenor, F.A. 2003. Internet facilities: use and non-use by Nigerian university scientists. Journal of Information Science, 29(I):35-48.

Ellsworth, J. 1994. Education on the Internet. Indianapolis: SAMS.

Gilster, P. 1997. Digital literacy. Etobicoke, Canada: John Wiley and Sons.

Gietzelt, D. 200I. Computer and Internet use among a group of Sydney seniors: a pilot study. Australian Academic and Research Libraries, 32(2): I37-152.

Harris, R. 2007. Evaluating Internet research sources. [Online]. http://www.virtualsalt.com/evalu8it.htm. Accessed 23 July 2007.

Healey, D. 2004. Advantages and limitations of computers and the Internet for classroom teachers. [Online]. http// oregonstate.edu/. (Accessed 20 November2004).

Hildreth, C.R. 1997. The use and understanding of keyword searching in a University Online Catalog. Information Technology and Libraries, 16(2): 52-62.

Hong, K.S., Ridzuan, A.A. \& Kuek, M.K. 2003. Students' attitudes toward the use of the Internet for learning: a study at a university in Malaysia. Educational Technology and Society, 6(2): 45-49.

Hu, C. 1996. Network literacy: new task for librarian on user education. Paper presented at the 62nd IFLA General Conference - Conference Proceedings, 25-3I August.

Jagboro, K.O. 2003. A study of Internet usage in Nigerian universities: a case study of Obafemi Awolowo university, lie-Ife, Nigeria. First Monday, 8(2). [Online]. http://firstmonday.org/issues/issue8_2/jagboro/index. Accessed 23 June 2002.

Jones, S. 2002. The Internet goes to college: how students are living in the future with today's technology. [Online]. http:// www.pewinternet.org/. Accessed I5August 2002.

Julien, H. \& Barker, S. 2009. How high-school students evaluate scientific information: a basis for information literacy skills development. Library and Information Science Research, 31(I): 12-17.

Kaur, A. \& Manhas, R. 2008. Use of Internet services and resources in the engineering colleges of Punjab and Haryana (India): a study. International Information and Library Review, doi:10.1016/j.iilr.2007.12.00I.

Ke, H.R. 2002. Exploring behaviour of e-journal users in science and technology. Library and Information Science Research, 24(3): 256-29I.

Kirk, E.E. 1996. Evaluating information found on the Internet. [Online]. http://www.library.jhu.edu/se/util/display_mod.cfm? Accessed 2 April 2009. 
Lancaster, S., Yen, D.C., Huang, A.H. \& Hung, S.Y. 2007. The selection of instant messaging e-mail college students' perspective for computer communication. Information Management and Computer Security, 15(I): 5-22.

Large, A., Tedd, L.A. \& Hartley, R.J. 1999. Information seeking in the online age: principles and practice. $2^{\text {nd }}$ edition. London: Bowker Saur.

Leelavathi, N. \& Doraswamy, M. 2007. Knowledge and use of digital library resources by engineering faculty members affiliated to Acharya Nagarjuna University, A.P. India. Paper read at the International Conference on Universal Digital Library, November 2, Posner Center, Carnegie Mellon University.

Lindsay, W. \& Mclaren, S. 2000. The Internet: an aid to student research or a source of frustration? Journal of Educational Media, 25(2): $115-128$.

Luambano, I. \& Nawe, J. 2004. Internet use by students at the University of Dar es Salaam. Library Hi Tech News, 10:13- 17.

Lubans, J. 1999. Key findings on Internet use among students. [Online]. http://www.firstmonday.dk/. Accessed 23 June 2003.

Madhusudhan, M. 2007. Internet use by research scholars in University of Delhi, India. Library Hi-Tech News, 24 (8): 36-42.

Martin, A. 2006. Literacies for the digital age: preview of Part I. Digital literacies for learning. London: Facet Publishing, pp. I-20.

McClure, R.C. 1994. Network literacy: a role of libraries? Information Technology and Libraries, 13(2): I I5- 125.

Meskill, C. \& Anthony, N. 2008. Computer mediated communication: tools for instructing Russian heritage language learners. [Online]. http://www.international.ucla.edu/languages/article.asp?parentid=77038. Accessed 20 November 2008.

Mgobozi, M.N. \& Ocholla, D.N. 2002. A comparison of the use of electronic journals for the dissemination of scholarly information by the University of Natal and University of Zululand. In: Bothma, T \& Kaniki, A (eds). Progress in Library and Information Science in Southern Africa. Proceedings of the Second Biennial DISSAnet Conference (ProLISSA2). Pretoria: Infuse, pp. 29-47.

Mishra, O.P., Yadav, Y. \& Kamini, B. 2005. Internet utilisation pattern of undergraduate students. University News, 43(I3): 8-12.

Monopoli, M., Nicholas, D., Georgiou, P. \& Korfiati, M. 2002. A user-oriented evaluation of digital libraries: case study the "electronic journals" service of the library and information service of the University of Patras, Greece. Aslib Proceedings, 54(2): 10-117.

Nachmias, R. \& Segev, L. 2003. Students' use of content in Web-supported academic courses. The Internet and Higher Education, 6: 145- 157.

Ngai, E.W.T., Law, C.C.H., Chan, S.C.H. \& Wat, F.K.T. 2008. Importance of the internet to human resource practitioners in Hong Kong. Personnel Review, 37(I): 66-84.

Nicholas, D. 2000. Assessing information needs: tools, techniques and concepts for the information age. London: Aslib.

Ngulube, P. \& Thompson, E.C.G. 2008. Influence of the World Wide Web on the citation patterns of Master of Information Studies students at the University of Natal during the period 1996 to 2002. South African Journal of Libraries and Information Science, 74(2): 160-170.

Norwegian Historian visits UniZulu. 2000. Umlozi Wezindaba 8(16): 5.

Odero-Musakali, D. \& Mutula, S.M. 2007. Internet adoption and assimilation in Kenyan university libraries. Library Review, 56(6): 464-475.

Oghenevwogaga, B.A. \& Oghenevwogaga, D.T. 2006. The impact of the internet on research: the experience of Delta State University, Nigeria. Library Philosophy and Practice, 8(2): 1-9.

Ojedokun, A. 200I. Internet access and usage by students of the University of Botswana. African Journal of Library, Archives and Information Science, II(2): 97-107.

Ojedokun, A. 2003. Internet access competence and the use of the Internet for teaching and research activities by University of Botswana academic staff. African Journal of Library, Archives and Information Science, I3(I): 43-53.

Olalude, F. 2007. Utilisation of Internet sources for research by information professionals in Sub-Saharan Africa. African Journal of Library, Archives and Information Science, I7(I): 53-58.

Olaniran, B.A. 2006. Applying synchronous computer-mediated communication into course design: some considerations and practical guides. Campus-Wide Information Systems, 23(3): 210-220.

Olatokun, W.M. 2008. Internet access and usage by secondary school students in a Nigerian Municipality. South African Journal of Libraries and Information Science, 74(2): I38-I 48.

Omotayo, B.O. 2006. A survey of Internet access and usage among undergraduates in an African university. The International Information and Library Review, 38: 215-224.

Payne, G. \& Payne, J. 2004. Key concepts in social research. London: Sage.

Perry, T.T. 1998. Internet use by university student: an interdisciplinary study on three campuses. Internet Research: Electronic Networking Applications Policy, 8(2): |36-141.

Regents of the University of California. 2008. Recommended search engines. [Online]. http://www.lib.berkeley.edu/TeachingLib/ Guides/Internet/SearchEngines.html. Accessed 2 April 2009.

Renwick, S. 2005. Knowledge and use for electronic information resources by medical sciences faculty at The University of West Indies. Journal of the Medical Library Association, 93(I): 2I-30.

Riahinia, N. \& Azimi, A. 2008. Women and the web: an evaluation of academic Iranian women's use of the internet in Tarbiat Moalem University. The Electronic Library, 26(I): 78-82.

Ruthven, I., Baillie, M. \& Elsweiler, D. 2007. The relative effects of knowledge, interest and confidence in assessing relevance. Journal of Documentation, 63(4): 482-504.

Salmon, F.C. 2002. A survey of Internet use by faculty at The University of the West Indies, Mona. Library and Information Association of Jamaica Bulletin: 31-35.

Savolainen, R. 2002. Network competence and information seeking on the Internet: from definitions towards a social cognitive model. Journal of Documentation, 58(2):21 I-226.

Savolainen, R. \& Kari, J. 2006. User-defined relevance criteria in web searching. Journal of Documentation, 62(6): 685-707

Scherer, K. 1997. College life online: healthy and unhealthy Internet use. Journal of College Student Development, 38(6): 655-65.

SA JnI Libs \& Info Sci 2009, 75(I) 
Scott, T.J. \& O'Sullivan, M.K. 2005. Analyzing student search strategies: making a case for integrating information literacy skills into curriculum. Teacher Librarian, 33(I):21-26.

Shezi, M.S. 2006. An investigation into the use of the internet by students at St. Joseph's Theological Institute, KwaZulu-Natal, South Africa. M.I.S. thesis. Pietermaritzburg: University of KwaZulu-Natal.

Spennemann, D.H.R. 2007. Learning and teaching 24/7: daily internet usage patterns at nine Australian universities. Campus Wire Information Systems 24(I): 27-44.

Spitzberg, B. \& Cupach, W.R. 1984. Interpersonal communication competence. Beverly Hills, CA: Sage.

Stevens, V. 2004. The skill of communication: technology brought to bear on the art of language learning. TESL-EJ, 7(4). [Online]. http://cwp60.berkeley.edu. I6080TESL-EJ/ej28/int.html. Accessed 20 October 2008.

Tsai, M.J. \& Tsai, C.C. 2003. Information searching strategies in web-based science learning: the role of Internet self-efficacy. Innovations in Education and Teaching International, 40(I): 43-50.

Vakkhari, P., Pennanen, M. \& Serola, S. 2003. Changes of search terms and tactics while writing a research proposal: a longitudinal case study. Information Processing and Management, 39: 445-463.

Urrehman, S. 2000. Internet use and capabilities of library and information professionals at the Kuwait University Libraries: results of a survey. Program, 34(2): 177-186.

Wang, P. \& Soergel, D. 1998. A cognitive model of document use during a research project. Study I. Document selection. Journal of the American Society for Information Science, 49(2): I I5-I33.

Weisband, S. \& Reinig, B.A. 1995. Managing user perceptions of email privacy. Communications of the ACM, 38(I2): 40-47.

Wen, J.R. \& Shih, W.L. 2006. Exploring the information literacy competence standards for elementary and high school teachers. Computers and Education, 50(2008):787-806.

Yuan, W. 1997. End-user searching behaviour in information retrieval: a longitudinal study. Journal of the American Society for Information Science, 48(3): 218-234. 